\title{
Complete recovery following "Veeram" (Mercury II chloride) poisoning: A case report
}

Sathiaruban $S^{1}$, Ghetheswaran $S^{1}$,Weerakkody $R M^{1}$

${ }^{1}$ Teaching Hospital of Jaffna.

\section{Abstract}

Veeram is a local term used in Nothern Sri Lanka, for impure mercury (II) chloride. $\left(\mathrm{HgCl}_{2}\right)$.

We describe a case with acute, suicidal, mercury (II) chloride poisoning, who presented with confusion, acidosis and renal shut down. He was managed with mercury chelation using penicillamine, and acutre renal failure with hemodialysis. He made a complete renal recovery on discharge, and on follow up he did not have any neurological symptoms, and have made a complete clinical recovery. Adiscussion on the acute mercury poisoning follows.

\section{Key words}

Mercury chloride, renal failure, chelation, hemodialysis

\section{Introduction}

Mercury is a metallic, heavy liquid at the room temperature, and one of the few metals that is liquid at room temperature - Francium, Cesium and Gallium being others. All forms of mercury (organic, elemental, and salts) are toxic. Manifestations of toxicity depends on nature (acute or chronic),intensity, and chemical form of mercury (1). Most human exposure results from fish consumption (organic mercury) or dental amalgam (metallic mercury). Kidneys are the prime target of mercury toxicity as it is primarily excreted through them (2). We describe a patient who consumed mercuric chloride with suicidal intent, and presented with typical manifestation of mercury poisoning, acute kidney injury and gastrointestinal erosions.

\section{Case Presentation}

A 38 year old, male goldsmith was admitted with 2 days history of oliguria, progressing to anuria, facial puffiness and leg edema. He gave a history of consumption of Veeram (mercury (II) chloride or mercuric chloride) three days back. He has consumed about $600 \mathrm{mg}$ of Veeram, however the exact dose of Mercury cannot be calculated as the purity of Veeram varies.

Soon after consumption he suffered burning sensation of the throat. He developed vomiting and severe prostration. His urine output gradually dropped and he developed facial and leg edema. He was admitted to the hospital confused. On examination, his heart rate was $92 / \mathrm{min}$, respiratory rate was $20 / \mathrm{min}$ and blood pressure was $130 / 90 \mathrm{mmHg}$.Examination of the respiratory system was unremarkable. Cyanosis, pallor, dyspnea or desaturation was not noticed. Rest of the examination was normal. His urine output after first six hours of admission was $0.1 \mathrm{ml} / \mathrm{kg} /$ $\mathrm{hr}$. His serum creatinine was $600 \mathrm{umol} / \mathrm{L}$, Urea $24 \mathrm{mmol} / 1$, serum potassium $6 \mathrm{mmol} / \mathrm{L}$, and sodium $136 \mathrm{mmol} / \mathrm{L}$. Arterial blood gas acidosis $(\mathrm{pH}=7.2$, [bicarbonate] $=18 \mathrm{mmol} / \mathrm{L})$ and hypoxia $\left(\mathrm{P}_{\mathrm{a}} \mathrm{O}_{2}\right.$ $=80 \mathrm{mmHg})$ of blood. His full blood count was normal. (See Table 1)

Table 1: Summary of the blood investigations

\begin{tabular}{|l|c|c|c|c|}
\hline $\begin{array}{l}\text { Mea- } \\
\text { sure }\end{array}$ & $\begin{array}{c}\text { Reference } \\
\text { range }\end{array}$ & $\begin{array}{c}\text { On } \\
\text { ad- } \\
\text { mis- } \\
\text { sion }\end{array}$ & $\begin{array}{c}\text { On } \\
\text { dis- } \\
\text { charge }\end{array}$ & $\begin{array}{c}\text { Most } \\
\text { abnor- } \\
\text { mal }\end{array}$ \\
\hline $\begin{array}{l}\text { Creati- } \\
\text { nine }\end{array}$ & $\begin{array}{c}40-100 \\
\text { umol/L }\end{array}$ & 600 & 100 & $600(\mathrm{H})$ \\
\hline Urea & $4-6 \mathrm{mmol} / \mathrm{L}$ & 24 & 6 & $24(\mathrm{H})$ \\
\hline $\mathrm{Na}^{+}$ & $\begin{array}{c}136-142 \\
\mathrm{mmol} / \mathrm{L}\end{array}$ & 136 & 138 & - \\
\hline $\mathrm{K}^{+}$ & $\begin{array}{c}3.5-5.5 \\
\mathrm{mmol} / \mathrm{L}\end{array}$ & 6.0 & 5.2 & $6.0(\mathrm{H})$ \\
\hline $\mathrm{CRP}$ & $<8 \mathrm{mg} / \mathrm{L}$ & 8 & 6 & - \\
\hline
\end{tabular}

$\mathrm{H}$ - Higher than reference range, $\mathrm{CRP}-\mathrm{C}$ reactive protein

His white cell count was $5800 / \mathrm{uL}$, neutrophils $76 \%$, lymphocytes $20 \%$. His hemoglobin was $110 \mathrm{~g} / \mathrm{L}$, platelet count was $456 \mathrm{k} / \mathrm{uL}$. 
An ultrasound scan of the kidneys showed acute renal parenchymal changes as increased echogenicity with normal kidney dimensions (right $=10 \mathrm{~cm}$, left $=10.4 \mathrm{~cm})$.

Due to acidosis and oliguria he was started on hemodialysis via a temporary femoral catheter. Hemodialysis was initiated with a two hour session and then was followed up with every other day four hour hemodialysis sessions. CRRT was not available at the time of presentation. We did not measure serum mercury levels due to unavailability in the local hospital.

Mercury chelation was tried with starting oral penicillamine $250 \mathrm{mg} 6$ hourly simultaneously. He underwent 6 cycles of hemodialysis, and then started producing urine. His renal functions got normalized at the end of 8 weeks. A full neurological examination performed six weeks later did not reveal any deficit. Based on the improvement of clinical symptoms, the chelation was stopped after two weeks. He was assessed by the psychiatric team and is under their care.

\section{Discussion}

Mercury is a metallic element distributed naturally in environment (3). There are three classes of mercury, with regards to clinical practice; metallic elemental mercury; inorganic mercury salts; and organic mercurial. Elemental mercury usually enters systemic circulation via the skin or inhalation. Acute poisoning of elemental mercury leads to corrosive bronchitis, pulmonary oedema, pulmonary fibrosis, diarrhea, renal dysfunction, visual and neuropsychiatry disturbances. Severe cases lead to death due to respiratory failure (4). Organic mercury compounds are absorbed from the intestine, converted to inorganic forms and have similar toxic effects. Organic mercury exposure causes neurological problems (5), such as visual field defects, defects of color vision, tremor, insomnia, memory loss, emotional labiality, depression, headache, peripheral neuropathy, and - 49 - $\operatorname{ataxia}(6)$.

Mercury (II) chloride is toxic and corrosive. It is still used as a wood preservative, photographic intensifier, disinfectant and in indigenous drug formulation and Ayurvedic remedies in Asian countries (7). Once ingested about $10 \%$ of mercuric chloride is absorbed through the gut. The lethal dose of mercuric chloride is $1-4 \mathrm{~g}$ per an adult. However fatalities have been reported with doses as small as $0.5 \mathrm{~g}(8)$. A search of literature shows eight cases of intentional mercury chloride poisoning. Interestingly two of the cases happened via intravenous route $(9,10)$, and the rest via oral intake (11).

Our patient consumed mercuric chloride with suicidal intention and developed acute renal failure

Franco et al. reported a case with mercuric chloride poisoning who developed two consecutive episodes of acute renal failure by two different mechanisms, a toxic and an immunological[20]. Our patient presented with acute renal failure and haemodialysis started on admission, chelation treatment also started same time. He recovered completely in two months period, serum creatinine became normal. It is likely that he had acute tubular necrosis rather than tubule-interstitial nephritis or immune glomerulopathy.

Measurement of mercury levels in blood( $>3.6$ $\mathrm{mg} / \mathrm{dL})$ and urine $(>15 \mathrm{mg} / \mathrm{dL})$ may be helpful in diagnosis of acute toxicity[7]. Treatment for acute ingestion includes activated charcoal for gastrointestinal decontamination, while emesis is contraindicated.

Chelation therapy should be considered for any symptomatic patient with a history of acute elemental mercury exposure. Chelating agents include dimercaprol, 2,3-dimercaptopropane1 -sulfonate, dimercapto-succinic acid and penicillamine. Plasma exchange appears to be the most efficient for inorganic mercury and it could be useful in association with chelation therapy at the early phase of the intoxication. The outcome 
depends on the form of the mercury compound and severity of exposure. Complete recovery occurs after mild exposure but usually fatal in severe toxicity. We did not do toxicological analysis and urine mercury levels. But he was started with chelating agent penicillamine as it was the only available chelation agent and has been used in acute mercury poisoning .

\section{Conclusion}

Acute mercury chloride toxicity has devastating effects. However prompt supportive treatment, and chelation therapy can provide significant recovery. Dialysis is an important supportive treatment.

\begin{abstract}
Abbreviations
CRP - C Reactive Protein, CRRT - Continuous Renal Replacement Therapy, DMSA Dimercaptosuccinic acid
\end{abstract}

\section{References}

1. Winek CL, Fochtman FW, Bricker JD, Wecht $\mathrm{CH}$ : Fatal mercuric chloride ingestion. Clin Toxicol 1981, 18(3):261-266.

2. Perazella MA: Renal vulnerability to drug toxicity. Clin J Am Soc Nephrol 2009, 4(7):1275-1283.

3. Taueg C, Sanfilippo DJ, Rowens B, Szejda J, Hesse JL: Acute and chronic poisoning from residential exposures to elemental mercury-Michigan, 1989-1990. J Toxicol Clin Toxicol 1992, 30(1):63-67.

4. Counter SA, Buchanan LH: Mercury exposure in children: a review. Toxicol Appl Pharmacol 2004, 198(2):209-230.
5. Vardhan V, Garg S: Mercury Toxicity - A Case Report. Med J Armed Forces India 2005, 61(1):76-78.

6. Gencpinar P, Buyuktahtakin B, Ibisoglu Z, Genc S, YilmazA, Mihci E: Mercury poisoning as a cause of intracranial hypertension. Journal of child neurology 2015, 30(6):760-763.

7. Sathe K, Ali U, Ohri A: Acute renal failure secondary to ingestion of ayurvedic medicine containing mercury. Indian J Nephrol, 23(4):301-303.

8. Beasley DM, Schep LJ, Slaughter RJ, Temple WA, Michel JM: Full recovery from a potentially lethal dose of mercuric chloride. J Med Toxicol, 10(1):40-44

9. Dittmann V, Pribilla O: [Suicide by intravenous injection of sublimate solution]. Zeitschrift fur Rechtsmedizin Journal of legal medicine 1985, 94(4):301-307.

10. Klinkmann H, Huebel A: testosterone treatment of severe intravenous mercuric chloride poisoning. Munchener medizinische Wochenschrift (1950) 1964, 106:1466-1468.

11. Boscolo M, Antonucci S, Volpe AR, Carmignani M, Di Gioacchino M: Acute mercury intoxication and use of chelating agents. Journal of biological regulators and homeostatic agents 2009, 23(4):217-223. 